\title{
Credit constraints and structure: a theoretical model of extractivism and slow-growth dynamics*
}

\author{
Restrições e estrutura de crédito: um modelo teórico de \\ extrativismo e dinâmica de crescimento lento
}

LEOPOLDO GÓMEZ-RAMÍREZ**

NESTOR GARZA***

\begin{abstract}
RESUMO: Desenvolvemos um modelo teórico que explica a relação entre restrições de crédito e crescimento econômico no contexto de uma economia de três setores, incluindo um setor "extrativo". O modelo faz parte da tradição estruturalista e se inspira na economia colombiana. Em contraste com os modelos de desenvolvimento econômico neoclássico, provamos que: 1) relaxar a contração do crédito promoveria o crescimento do setor formal, mas pode, no entanto, não implicar no crescimento do emprego formal; e 2) a economia pode convergir para um padrão em que o setor extrativo aumenta enquanto o formal diminui. PALAVRAS-CHAVE: Restrições de crédito; emprego formal; extrativismo; Colômbia; economia estruturalista.
\end{abstract}

ABSTRACT: We develop a theoretical model that explains the relationship between credit constraints and economic growth in the context of a three-sector economy, including an "extractive" sector. The model belongs in the structuralist tradition and it is inspired by the Colombian economy. In contrast to neoclassic development economics models, we prove that: 1) relaxing the credit crunch would foster formal sector growth but it may nevertheless not imply formal employment growth; and 2) the economy can converge to a pattern where the extractive sector increases while the formal one shrinks.

KEYWORDS: Credit constraints; formal employment; extractivism; Colombia; structuralist economics.

JEL Classification: O11; O41; E24; E26.

\footnotetext{
* An earlier version of this paper was presented at the 45th Eastern Economists Association Conference, New York, 2019. We thank participants in this conference and the anonymous referees for helpful comments and suggestions. We also thank Peter Skott for his comments and contributions to this paper. He is a virtual coauthor. The usual disclaimers apply.

** Universidad del Norte, Barranquilla, Colombia.E-mail: leopoldog@uninorte.edu.co. Orcid: https:// orcid.org/0000-0002-9846-6014.

***California State University Dominguez Hills, California, USA. E-mail: ngarza@csudh.edu. Orcid: https://orcid.org/0000-0003-2038-1368. Submitted: 12/December/2019; Approved: 15/September/2020.
} 


\section{INTRODUCTION}

It is consensually accepted that credit constraints may be growth deterring (Fazzari et al.., 1988; Banerjee and Duflo, 2014; Khwaja and Mian, 2008). However, there has been little theoretical work, particularly in the case of developing economies (Skott and Gómez-Ramírez, 2018). In particular, a prominent feature of some developing economies has not been considered from a theoretical perspective. It is that beyond the typical formal-informal duality there may be a third, "extractive" sector. Companies in this sector reap the benefits of exploiting the domestic economy resources but leave little of them in it, because they neither hire too much employment nor significantly contribute to domestic consumption or investment. In this paper we theoretically examine the role of credit constraints in such "three-sector" economy.

The theoretical inquiry we present here is inspired by the contemporary Colombian economy. This country is characterized by relatively hard but improving credit restrictions, it also exhibits the typical formal/informal dualism of developing economies and portrays an increasingly important "extractive" sector (coal, and to a lesser degree oil mining). Our model highlights dynamic features that existing theoretical approaches have not yet acknowledged, although already incorporated in applied empirical analyses (Eslava et al., 2010; Villar et al.., 2005).

In this paper we make two contributions. 1) It is shown that relaxing the credit crunch would foster formal (modern) sector growth, but it may nevertheless not imply formal employment growth. Thus, supplementary policies seem necessary to achieve the latter. In addition: 2 ) it is shown that in a three-sector economy it is possible that the economy converges to a growth pattern in which the extractive sector increases but the formal one shrinks. The model proves that improving access to credit would reduce the likelihood of converging to such undesirable pattern.

This paper belongs in the literature where economic dualism is dynamically modelled in relationship to trade and accumulation (Ros, 2013b). Our most immediate references are Skott and Gómez-Ramírez (2018), and Gómez-Ramírez (2019), who examine credit constraints and growth in Mexico. We however offer an extended model, the case of an economy which also exhibits a third, "extractive" sector. ${ }^{1}$ In our three-sector economy the extractive sector pretty much just exploits the local economy. At the same time, however, the formal and informal sectors contribute to domestic growth and neither of them is insignificant. In other words, we discuss the case of an economy in which converging to the (clearly most desired) pattern of formal sector enlargement is a real possibility. It is not necessarily trapped in extractivism or informality. Our model shows that although relaxing credit con-

\footnotetext{
${ }^{1}$ Recent contributions have gone into examining the nuances of inflation-targeting and fiscal policy in the context of developing economies (Martins and Skott, 2020; Skott, 2021). In particular, Skott (2021) extends its fiscal policy discussion to the case of a three-sector economy in which the third sector is similar in spirit to the one of this paper.
} 
straints may allow this economy to escape from the "growth trap" of an ever enlargement of extraction, simultaneous supplementary employment policies are necessary to increase formal sector jobs.

It is worth mentioning that although the Colombian experience provides the primary motivation for this paper, the theoretical arguments are of a general kind and apply more widely. Other developing countries with an important extractive sector might show similar patterns.

The paper is organized as it follows. After this introduction, the second section presents a literature review on credit constraints and growth, emphasizing the Colombian case. The country is then portrayed as fitting our characterization of a three-sector economy. Third section presents the baseline theoretical model, and the first of our findings. Fourth section extends the analytical dynamic results. It presents our second finding, which is that relaxing credit restrictions could help putting the economy out of the extractivist "growth trap". We offer brief concluding comments in fifth section.

\section{CREDIT RESTRICTIONS, INFORMALITY AND THE EXTRACTIVE SECTOR IN COLOMBIA}

Colombian economic growth has been slow but stable in the long-run, and its average slightly superior to other Latin American economies. In the period 19252019 there have been only two episodes of negative growth (1929-31 and 1999). This long run growth rate has however decelerated, with a structural break towards lower rates since the 1980s.

During the first half of the 20th century growth was heavily dependent on coffee exportations, slowly evolving to manufacturing industry and internal consumption as growth drivers until the 1980s (Ortiz et al.., 2013). Nominally, the country pursued Import-Substitution-Policies (ISI) during the 1940s to 1980s (Ocampo et al.., 2015). However, the commitment with ISI policies was not so intense. For example, the channeling of financial resources towards the manufacturing industry was not extraordinary when compared to other Latin American countries (Brando, 2016). In fact, sector-oriented finance was implemented only by the end of the 1970s, and contrary to most developmentalist policies in the region: a) it was directed to construction as leading sector; and b) did not directly financed the sector, but created the institutional architecture to channel inhabitants' savings in that direction. When this sector-oriented finance policy was abandoned in the 1990s, banking penetration was still remarkably low and interest rates remarkably high. In other words, its effect on relaxing financial restrictions was low (Garza, 2016).

The relative stagnation of the 1980s gave way to neoliberal reforms in 1990-91. However, those reforms have had at least three unexpected results: a) an increase of government participation in the GDP; b) the stagnation of exportations as a percentage of GDP, and an increase of the participation of mining products in the 
exportations; and c) lower growth rates when compared to the period 1960s-1980s (Zerda, 2015).

Colombia has been unable to sustain high rates of capital accumulation in the long run, not just because of low saving rates, but because of the relatively low degree and quality of its financial intermediation (Castro et al.., 2017; Gutiérrez and Murcia, 2015; Díaz, 2014; and Delgado, 2004). Thus, we believe the country may be showing a situation akin to one of the scenarios modeled below: a small open economy with credit restrictions in which the modern sector losses participation in relation to the mining (extractive) sector, and in which workers are then expelled into survivalist informality.

Additional institutional problems include the internal armed conflict, drug trafficking and corruption, which have contributed to high risk finance and lack of entrepreneurial development. This feature has been captured by the growth accounting exercises of Yepes and Restrepo-Tobon (2016), Restrepo et al.. (2014), Eslava et al.. (2010) and Restrepo and Restrepo (2007). The contemporary Colombian economy is then reasonably well described as having: a) lack of access to finance; b) a foreign-owned and exportations-oriented mining (extractive) sector; c) a small modern sector however able to export manufactures and services; and d) an informal sector for domestic consumption. These are the elements of our modelling strategy.

\section{THE MODEL}

Consider an economy composed of three sectors: extractive $\left(Y_{0}\right), \operatorname{modern}\left(Y_{M}\right)$, and informal $\left(Y_{N}\right)$. Using the modern goods as numeraire, output in period $t$ is:

$$
Y_{t}=p_{O t} Y_{O t}+p_{N t} Y_{N t}+Y_{M t}
$$

in which $p_{0 t}$ and $p_{N t}$ are the relative prices of the extractive and the informal good, respectively, in period t.

\section{Extractive Sector}

The extractive sector has an exogenously determined growth rate $\rho$. It creates low or null jobs and it does not use other domestic production factors. Consequently, we assume the employment in this sector to be zero $\left(L_{0 t}=0\right)$. In some sense, beyond its accounting contribution to GDP, this sector does not really "add" to local economy development because it does not hire domestic labour nor hires domestic inputs. This is why we say it is an "extractivist" sector. We also assume its price and production are determined by the exogenously given international demand:

$$
\widehat{p_{O t} Y_{O t}}=\widehat{p_{O t}}+Y_{O t}=\rho
$$




\section{Informal Sector}

The informal good is consumed domestically (it is not exported), and it uses only labour as production factor; clearly, this is a stylized version of the fact informality exhibits very low capital intensity. Labour force grows at the exogenous rate $n$ :

$$
L_{t}=n
$$

The workers who cannot obtain a job in the modern sector, are then employed in the informal sector. Letting $L_{i t}$ be employment in sector $i$ in the period $t$, we have:

$$
L_{N t}=L_{t}-L_{M t}
$$

The production function is linear. $E_{t}$ is effective employment in the informal sector (thus $0<E_{t}<L_{N t}$ ) and $e_{t}=\frac{E_{t}}{L_{t}}$ is its effective employment rate (thus $\frac{E_{t}}{L_{N t}}=1-\frac{L_{N}-E_{t}}{L_{N t}}$, and $\frac{L_{N t}-E_{t}}{L_{N t}}$ is the rate of "hidden unemployment" in the informal sector). So

$$
Y_{N t}=E_{t}=e_{t} L_{N t}=e_{t}\left(L_{t}-L_{M t}\right)
$$

The informal sector uses only labour. Consequently:

$$
\omega_{N t}=e_{N t} p_{N t}
$$

in which $\omega$ is the average wage of a worker in the informal sector (in terms of formal goods) after taking into account under-employment.

\section{Modern Sector: production function heterogeneity}

The modern sector is capital-intensive and it does not exhibit under-employment. It produces goods for either domestic consumption or exports. In this paper, and differently from most contributions on investment decisions, we do not assume a representative firm. Instead, we assume productive heterogeneity. The modern sector has a large number of firms, with Leontief production functions and capital and labour as production factors. The capital productivity $\sigma$ is time-constant for all the firms. In contrast, the labour productivity $A_{i t}$ is firm-specific and timegrowing:

$$
y_{i t}=\min \left\{\sigma k_{i t}, A_{i t} l_{i t}\right\}
$$

In (7) $y_{i t}$ is output, $k_{i t}$ is capital stock, and $l_{i t}$ is labour, for every firm $i$ in period $t$. We focus on long-run issues, which is why we assume away labour hoarding in this modern sector. We assume average capital productivity $(\sigma)$ as exogenous. Aggregate capital is given therefore by $K_{t}=\sum_{i_{i}} k_{i t}$, aggregate employment by $L_{M t}=\sum_{i} l_{i t}$, and average labour productivity by $A_{t}=\frac{\sum_{i} A_{i t} t_{i t}}{L_{M t}}$.

Here it is worth highlighting we acknowledge that perhaps formal firms' production exhibits some degree of inputs substitution, and not the stark complementarity of a Leontief production function. In fact, we explicitly acknowledge our choice of a Leontief (instead of a, say, CES one) is to some extent done because it simplifies the model. On the other hand, however, we believe that this choice actually strengthens the first important result of our model (that the effect of improving 
financial markets on formal employment growth is ambiguous, and supplementary policies are needed). This is because, if under the assumption of capital-labour complementarity, we could conclude that fostering capital accumulation (via relaxing the credit constraints) does not guarantee formal employment growth as well, then the same result would be actually stronger if we assumed capital could replace labour. Furthermore, there are literature contributions examining dual, developing economies in which Leontief production function for their formal sector firms have been chosen as well (Skott and Gómez-Ramírez, 2018; Skott, 2021).

Given that said, from (7) it follows that:

$$
Y_{M t}=u \sigma K_{t}=A_{t} L_{M t}
$$

in which $u$ is average capital use. We can see that the modern sector growth rate is positively related to: a) the rate of accumulation, b) the rate of labour productivity, and c) the rate of employment; $\widehat{Y}_{M t}=\widehat{K}_{t}=\hat{A}_{t}+\widehat{L}_{M t}$.

\section{Technical Progress}

Let us say that if firm $i$ innovates in period $t$, it has "high" productivity. In any other case, it uses the baseline technology from the former period $t$ and it has "low" productivity. We assume $A_{i t}=\exp \left(a_{t}+b_{i t}\right)$ or, equivalently:

$$
\ln A_{i t}=a_{t}+b_{i t}
$$

in which $a_{t}$ is the baseline technology, and:

$$
b_{i t}=\left\{\begin{array}{cc}
b & \text { with probability } x \\
0 & \text { with probability } 1-x
\end{array}\right.
$$

In (10) $b_{i t}$ describes innovation, and it follows a random process. Each firm has a probability $x \in[0,1]$ of innovating during some period. The stochastic variable $b_{i t}$ is independent between firms and serially independent for each firm $\left(b_{i t}\right.$ is independent from $b_{i t}$ if $i t \neq j \tau$ ).

There is technology diffusion: $a_{t}$ is function of time and firms learn from past innovations. Diffusion is in this sense more than just passive adoption of existing techniques, because by refining and combining the existing innovations, the baseline technology can determine a higher productivity than the one reached by last period innovative firms (i.e., $a_{t+1}>a_{t}+b$ ). The combination process, in turn, depends of innovations visibiity and use extension. We assume that:

$$
a_{t+1}=a_{t}+f\left[\ln A_{t}-a_{t}\right]+g[R] ; f^{\prime}>0, g^{\prime} \geq 0
$$

in which $R_{t}=\ln \frac{K_{t+1}}{K_{t}}$ is the accumulation rate (in discrete time). The function $f$ [.] represents the diffusion process. The second term of the right-hand side of (11), the function $g$ [.], comes from traditional "learning by doing" logic. It respects "Verdoorn Law" according to which accumulation positively affects productivity growth. ${ }^{2}$

\footnotetext{
2 Examples of this connection in Latin American countries can be seen in Skott and Larudee (1998) and Ros (2013a, chapter 1), which emphasizes Mexico.
} 


\section{Credit Restrictions, Productivity, and Employment}

A comment about the notion of credit market supplier we have in this paper is important to offer here. We are fairly aware in many developing economies households and firms' savings are transmitted into firms' investment not only through formal banking and/or other formal financial institutions systems. ${ }^{3}$ In these contexts, perhaps even some formal firms recur to informal loans suppliers. So, the credit markets we posit in this paper do not need to be interpreted in the narrow sense of a formal banking and/or other financial institutions system. Any loan supplier transmitting households and firms' savings into formal firms' investment could be included in our model.

Given that said, credit restrictions can affect both $\ln A_{t}-a_{t}$ and $R_{t}$. We use a stylized case where capital depreciates completely after one period, and where the firm knows if it will be innovating in period $t+1$. It then takes its investment decisions at $t, I_{i t}$. Two extreme cases of credit restrictions will exemplify their effect on productivity and technological progress: a) total restriction, and b) perfectly functioning capital markets.

In the first polar case, complete credit restrictions, firms invest using only their own cash-flows. If they invest the same proportion of their operating profits, and given the random distribution of innovations, a proportion $x$ of the total capital stock will be operated by innovative firms. In turn, non-innovative firms will operate a proportion $1-x$ of the capital stock:

$$
\begin{aligned}
& K_{t}^{\text {high }}=x K_{t} \\
& K_{t}^{\text {low }}=(1-x) K_{t}
\end{aligned}
$$

The average productivity in the modern sector is:

$$
A_{t}=\frac{\sum_{i} A_{i t} l_{i t}}{\sum_{i} l_{i t}}
$$

We have production factors complementarity, and high and low productivity firms co-exist. Consequently:

$$
A_{t}=\frac{K_{t}}{\frac{x K_{t}}{\exp \left(a_{t}+b\right)}+\frac{(1-x) K_{t}}{\exp \left(a_{t}\right)}}=\frac{\exp \left(a_{t}+b\right)}{x+(1-x) \exp (b)}
$$

And:

$$
\ln A_{t}=\ln \left(\frac{\exp \left(a_{t}+b\right)}{x+(1-x) \exp (b)}\right)=a_{t}+b-\ln (1+(1-x)(\exp b-1))
$$

For $b$ sufficiently small:

$$
\ln A_{t}=a_{t}+x b
$$

\footnotetext{
${ }^{3}$ In the city of Barranquilla, for example, it is well-known that informal (and rather shady) loan suppliers known as the "gota a gota" do supply large sectors of the city population (https://www.elheraldo.co/ mas-negocios/cuesta-caro-ser-pobre-nuestros-locales-hombres-de-kabul-682800). And it is well-know this phenomenon extends to many developing economies (Banerjee and Duflo, 2011, chapter 7).
} 
Using (11) y (14) we obtain an expression for average productivity growth:

$$
\begin{aligned}
& \hat{A}_{t}=\ln \left(\frac{A_{t+1}}{A_{t}}\right)=\ln A_{t+1}-\ln A_{t}=a_{t+1}-a_{t} \\
& A_{t}=f[x b]+g[R]
\end{aligned}
$$

The employment growth in the modern sector is given by:

$$
\overleftarrow{L}_{M t}=\ln \left(\frac{L_{M t+1}}{L_{M t}}\right)=\ln \left(\frac{K_{t+1}}{K_{t}} \frac{A_{t}}{A_{t+1}}\right)=R_{t}-A_{t}
$$

By using (15) it is obtained:

$$
\tilde{L}_{M t}=R_{t}-f[x b]-g[R]
$$

In the other polar case, perfectly functioning capital markets, all investment is allocated into high productivity firms. When all the economy pays the same wage (a likely situation in presence of a large informal sector with under-employment, an "industrial reserve army") innovative firms obtain all the credit. In such a case, non-innovative firms prefer to invest in the innovative ones with higher profits, instead that on themselves with lower profits. By assuming total depreciation, instead of (12)-(13) now we have:

$$
\begin{aligned}
& K_{t}^{\text {high }}=K_{t} \\
& K_{t}^{\text {low }}=0
\end{aligned}
$$

And by following the same steps as in obtaining (15) and (16), we find that perfect capital markets determine the productivity and formal employment growth rates as given by:

$$
\begin{aligned}
& \hat{A}_{t}=f[b]+g[R] \\
& \hat{L}_{M t}=R_{t}-f[b]-g[R]
\end{aligned}
$$

It could be seen that (19) is larger than (15): perfect capital markets imply greater labour productivity growth. Also notice $\hat{A}$ increases in $x$, the inverse of credit restrictions. In other words, labour productivity is inversely related with credit constraints:

$$
\hat{A}=\ln \frac{A_{t+1}}{A_{t}}=f[x]+g[\hat{R}]
$$

The effect of improving financial markets on formal employment growth is, however, ambiguous. This can be appreciated by comparing (16) and (20): we cannot know in advance which is larger. The intuition of this ambiguity is straightforward: on the one hand better functioning credit markets increase capital accumulation, but on the other hand they also increase labour productivity (and by definition

\footnotetext{
${ }^{4}$ In this case, and in contrast to (15), the expression for: $\ln A_{t}(19)$ is exact. We do not need a logarithmic proxy.
} 
it means more output can be produced with the same labour input). We cannot know a priori which effect would be stronger. All we do know is that:

$$
\hat{L}_{M}=\ln \frac{L_{M_{t+1}}}{L_{M_{t}}}=R-(f[x]+g[R])
$$

In (22) we cannot posit one effect as stronger than the other. But this equation makes explicit that supplementary (to improving credit access) policies aimed to directly affect capital accumulation are needed if its effect is going to prevail against the labour productivity increase one. And note this is specially the case because, due to the learning by-doing effects (captured with $g[R]$ ), capital accumulation has indirect positive effects on labour productivity as well. In sum, there is no guarantee that modern sector growth will also go hand in hand with increasing formal employment. Supplementary policies are needed to achieve the latter.

\section{PROFIT RATE AND ACCUMULATION}

The capital good is produced combining informal and modern goods using a Cobb-Douglas production function:

$$
I_{t}=B A_{t}^{1-\alpha} I_{N t}^{1-\alpha} I_{M t}^{\alpha}
$$

in which the capital good $I$, is produced using $I_{N}$ and $I_{M}$ inputs from the informal and modern sectors respectively. Just like in the modern sector, there is technological progress when making investment goods out of informal and modern goods. It could be verified that the production functions $Y_{M}$ and $Y_{N}$ determine the same labour-saving technological progress rate for the investment goods as for the modern sector ones. ${ }^{5}$ Using once again the modern goods price as numeraire, cost minimization implies that:

$$
\frac{A_{t} I_{N t}}{I_{M t}}=\left(\frac{\alpha}{1-\alpha} \frac{p_{N t}}{A_{t}}\right)^{-1}
$$

By solving the optimization, we have that the cost (= price) by unit of investment (in terms of modern goods) is:

$$
p_{I t}=\frac{\left(\frac{\alpha}{1-\alpha}\right)^{1-\alpha}+\left(\frac{\alpha}{1-\alpha}\right)^{-\alpha}}{B}\left(\frac{p_{N t}}{A_{t}}\right)^{1-\alpha}
$$

Choosing appropriate units and setting $B=\left(\frac{\alpha}{1-\alpha}\right)^{1-\alpha}+\left(\frac{\alpha}{1-\alpha}\right)^{-\alpha}$ this expression reduces to

$$
p_{I t}=\left(\frac{p_{N t}}{A_{t}}\right)^{1-\alpha}
$$

A firm's investment is determined by: a) profits of newly invested units, and b) credit restrictions. Investment can be positive function of current profits, but neg-

\footnotetext{
${ }^{5}$ Using (5) and (8) we have: $I_{t}=B A\left(e L_{N}\right)^{1-\alpha}\left(L_{M}\right)^{\alpha}$.
} 
ative one of the investment goods' price. Without credit restrictions the effect of current profits most likely would be small, and investment would be determined by expected demand and current capacity use. With credit restrictions the influence of profits would be higher, because they are a primary source of funding.

It is however expected that labour market conditions will exert an effect on the accumulation rate: labour mobility is not perfect and wages in the modern sector are typically higher than in the informal one:

$$
\omega_{M t}=\left(1+\mu_{t}\right) \omega_{N t}
$$

in which $\omega_{M}$ is the real wage in the modern sector (in terms of modern goods) and $\mu_{T}$ is "wage premium". Firms can attract workers using such premium, without increasing the wages in the informal sector. The participation of profits in the modern sector will be ${ }^{6}$

$$
\pi_{t}=1-\frac{\omega_{M t}}{A_{t}}
$$

Consequently, given the profits participation, the wage premium is inversely related to $\frac{\omega_{N t}}{A_{t}}$ (and the premium will be ${ }^{1+\mu_{t}}=\frac{1-\pi}{\left(\omega_{N t}\right)}$ ).

Therefore, the aggregate accumulation rate and its properties will be:

$$
\begin{gathered}
R_{t}=\frac{I_{t}}{K_{t}}=F\left[\pi_{t}, p_{I t}, x, \frac{\omega_{N t}}{A_{t}}\right] ; \\
F_{1}>0, F_{2}<0, F_{3}>0, F_{4}<0
\end{gathered}
$$

in which $x$ is an indicator of the firms' ability to obtain credit (inverse of credit restrictions severity).

\section{Demand Structure and Wage Determination}

According to the Cobb-Douglas specification in (24), investment spending is divided between the modern and informal good at a constant proportion $1-\alpha$ for the informal one. Assuming a balanced trade account (net exportations $=0$ ), we have:

$$
\begin{gathered}
p_{N t} Y_{N t}=(1-\alpha) Y_{t} \\
p_{N t} Y_{N t}=(1-\alpha)\left(p_{O t} Y_{O t}+p_{N t} Y_{N t}+Y_{M t}\right)
\end{gathered}
$$

By using (4)-(6) and (8), the proportion of wages in the modern sector is determined by its interaction with the informal sector:

\footnotetext{
${ }^{6}$ Profit participations are different among firms, because of differences in labour productivity: $\pi_{i t}=1-\frac{\omega_{M t}}{A_{i t}}$. By combining this expression with the productivity assumptions in (9) and (10), we have:

$\pi_{t t}=1-\frac{\omega_{M t}}{A_{t t}}=\left\{\begin{aligned} \pi_{t t}=1-\frac{\omega_{M t}}{\exp \left(a_{t}\right)}=\pi_{t}^{t a w} & \text { for a non-innovative firm } \\ \pi_{t t}=1-\frac{\omega_{M t}}{\exp \left(a_{t}+b\right)}=\pi_{t}^{h t g h} & \text { for an innovative firm }\end{aligned}\right.$

in which $\pi_{t}^{\text {low }}$ and $\pi_{t}^{\text {high }}$ the profits participation.
} 


$$
\omega_{N t}\left(L_{t}-L_{M t}\right)=\frac{1-\alpha}{\alpha}\left[p_{O t} Y_{O t}+\bar{u} \sigma K_{t}\right]
$$

Dividing by ${ }_{A L}\left(\frac{L-L_{M}}{L}\right)$ obtain:

$$
\frac{\omega_{N t}}{A_{t}}=\frac{1-\alpha}{\alpha}\left[\frac{\frac{p_{O t} Y_{O t}}{A_{t} L_{t}}+\frac{\bar{u} \sigma K_{t}}{A_{t} L_{t}}}{1-\frac{\bar{u} \sigma K_{t}}{A_{t} L_{t}}}\right]
$$

The participation of wages in the modern sector is $\left(1+\mu_{t}\right)\left(\frac{\omega_{N t}}{A_{t}}\right)$. From $(32)$ it could be seen it is positively related to the capital/effective-labour ratio, $\frac{K}{A L}$, and to the extractive sector growth/effective-labour ratio, $\frac{p_{o t} Y_{O t}}{A_{t} L_{t}}$. If these ratios increase, modern sector wages would increase, de-incentivizing investment. The equilibrium condition for the modern sector, the IS condition, can be used to determine the wage premium: aggregate investment must equal aggregate savings in a closed economy (or in an open one with a balanced trade account). This assumption is consistent with the Colombian case, where the net exports deficit has never been too high (less than $10 \%$ of GDP). In fact, before the 2000s it was close to zero (Garcia, 2002). We have:

$$
p_{I t} I_{t}=s \pi_{t} Y_{M t}
$$

in which $s$ is savings as percentage of profits. By using (8), (29) and (33) we have:

$$
p_{I t} F\left[\pi_{t}, p_{I t}, x, \frac{\omega_{N t}}{A_{t}}\right]=s \pi_{t} \bar{u} \sigma
$$

in which $\frac{\omega_{N t}}{A_{t}}$ is determined by (32). Assuming the implicit function theorem conditions hold and, in particular, assuming $p_{l} \frac{\partial F}{\partial \pi}-s \bar{u} \sigma \neq 0$ in (34), we have:

$$
\begin{gathered}
\pi_{t}=\pi\left[s, p_{I t}, x, \frac{\omega_{N t}}{A_{t}}\right] ; \\
\pi_{1}<0, \pi_{2} \gtreqless 0, \pi_{3}>0, \pi_{4}<0
\end{gathered}
$$

The partial derivatives are obtained under the assumption that $p_{I} \frac{\partial F}{\partial \pi}-s \bar{u} \sigma<0$, a plausible condition.

\section{DYNAMIC FEATURES}

By combining (2), (3), (22) (29), (32) and (35) we obtain general expressions for the growth rates of $\frac{K}{A L}$ and $\frac{p_{O} Y_{O}}{A L}$ :

$$
\begin{aligned}
\frac{\mathbb{R}}{A L}=R-\hat{A}-\hat{L}= & F\left[\frac{K}{A L}, \frac{p_{o} Y_{o}}{A L}, x\right]-f[x]-g\left[F\left[\frac{K}{A L}, \frac{p_{o} Y_{o}}{A L}, x\right]\right]-n \\
& =\psi\left[\frac{K}{A L}, \frac{p_{o} Y_{o}}{A L}, x\right] \text { with } \psi_{1}<0, \psi_{2}<0, \psi_{3} \gtreqless 0
\end{aligned}
$$




$$
\begin{aligned}
\frac{\widehat{p_{o} Y_{O}}}{A L}=\rho-\hat{A}-\hat{L} & =\rho-f[x]-g\left[F\left[\frac{K}{A L}, \frac{p_{o} Y_{O}}{A L}, x\right]\right]-n \\
& =\chi\left[\frac{K}{A L}, \frac{p_{o} Y_{O}}{A L}, \chi\right] \text { with } \chi_{1}>0, \chi_{2}>0, \chi_{3}>0
\end{aligned}
$$

(36)-(37) describe the dynamics of this economy. For any value of $x$, they describe a $2 \mathrm{D}$ autonomous system of differential equations.

\section{Three Scenarios}

The dynamic system described by (36)-(37) does not have internal steady-state point. Excluding the razor-edge scenario (scenario 3 below), one of the two state variables asymptotically approaches zero, the participation of the modern or extractive sectors in the total labour, disappears. We can see this feature by noticing that the system's structure is such that the level curves of the two growth rates coincide: the set of values $\left(\frac{K}{A L}, \frac{p_{O} Y_{o}}{A L}\right)$ where $R-\hat{A}-\hat{L}=c_{1}$ for any constant $c_{1}$, will also satisfy $\widehat{p_{o}}+\widehat{P}_{o}-\widehat{A}-\tilde{L}=c_{2}$ for any constant $c_{2}$. They configure three scenarios.

Scenario 1: growth of the extractive sector. Here $\widehat{p}_{o}+\widehat{Y}_{o}-\hat{A}-\hat{L}>0$ when $\widehat{R}-\hat{A}-\hat{L}=0$. We illustrate this possibility in Figure 1. The locus $R-\hat{A}-\hat{L}=0$ lies above the locus $\widehat{p}_{o}+\widehat{P}_{o}-\widehat{A}-\widehat{L}=0$. Except the corner solutions where $K=0$ and/or $Y_{o}=0$, we do not have steady-states. If we start from any initial situation such that $\frac{K}{A L}>0, \frac{p_{O} Y_{O}}{A L}>0$, the system diverges towards $\frac{K}{A L} \rightarrow 0$ and $\frac{p_{o} Y_{O}}{A L} \rightarrow \infty$. This configuration represents the case where income growth in the extractive sector exceeds the minimum sustainable growth rate of the modern sector $\rho>R$. If our concern is only income growth, without caring for labour effects, this would be a desirable divergence.

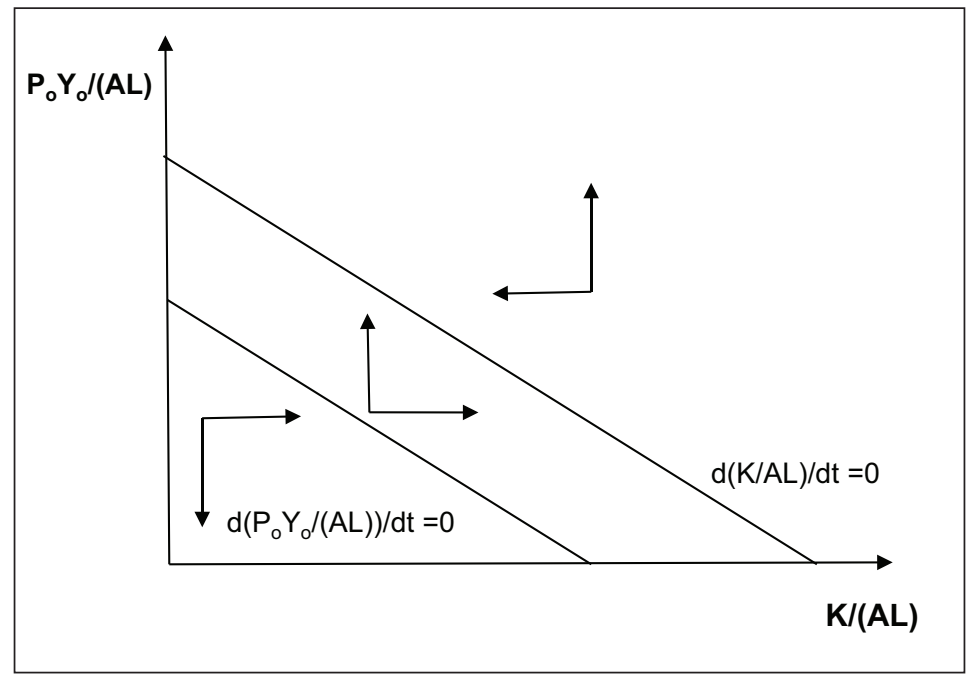


Scenario 2: potential "growth trap". If $\widehat{p}_{o}+\widehat{Y}_{o}-\widehat{A}-\hat{L}<0$ when $\widehat{R}-\hat{A}-\hat{L}=0$. This possibility is represented in Figure 2. The locus $R-\hat{A}-\hat{L}=0$. now lies below the locus $\widehat{P}_{o}+\widehat{T}_{o}-\widehat{A}-\widehat{L}=0$. This configuration produces different results, depending on the initial $\frac{K}{A L}$ and $\frac{p_{O} Y_{O}}{A L}$ values. If the they lie under the SS curve, there will be convergence to the stationary point $E_{1}$, in which the modern sector increases its participation. This is most likely a convenient result for the laborers. However, SS initial states once again determine divergence in $\frac{K}{A L} \rightarrow 0$ and $\frac{p_{O} Y_{O}}{A L} \rightarrow \infty$. The curve SS describes the stable saddle path associated to the $E_{2}$ stationary state, where the modern sector disappears and the extractive sector increases. The curve SS represents a "growth trap": initial states above it determines the elimination of the modern sector.

Figure 2: Scenario 2 - potential "growth trap"

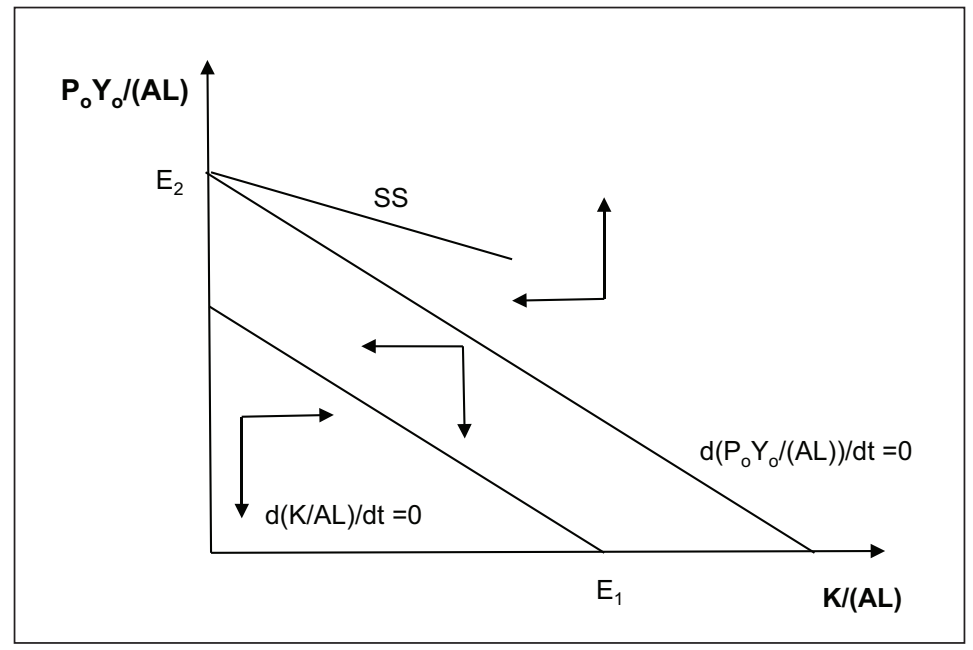

Scenario 3: the "razor-edge". This scenario is depicted in Figure 3, with a continuum of steady-states. Depending upon the parameters it generates hysteresis, because every stationary point can be obtained depending the initial values. In this scenario, destabilizing forces which send us either towards the scenario 1 (when above the locus) or towards $E_{1}$ (when lying below) could predominate.

\section{Credit Restrictions and Growth Patterns: Analysis}

Credit improvement shifts the two loci. The $\widehat{p}_{o}+\widehat{P}_{o}-\hat{A}-\tilde{L}=0$ shifts upwards. The shift of $R-A-\mathcal{L}=0$ is however ambiguous. In Appendix 1 we show how one can move the economy from scenario 2 to scenario 1 (or by accident, to scenario 3 ).

Notice that in scenario 1 the improvement in access to credit increases growth in the modern sector $(R)$, increasing average growth throughout the economy. Assuming that the economy does not move into scenario 2 (the shifts are not such that the locus $\widehat{p}_{o}+\widehat{Y}_{o}-\hat{A}-\hat{L}=0$ lies above $\widehat{R}-\hat{A}-\hat{L}=0$ ), this increase is then temporary and the economy will eventually converge to the situation where $\frac{K}{A L} \rightarrow 0 \mathrm{y} \frac{p_{O} Y_{O}}{A L} \rightarrow \infty$. The 
modern sector asymptotically moves towards disappearance and per capita income equals $\rho-\mathrm{n}$. In this case, "per capita" literally means nothing for the laborers because the extractive sector does not use labour.

Figure 3 - Scenario 3: the "razor-blade"

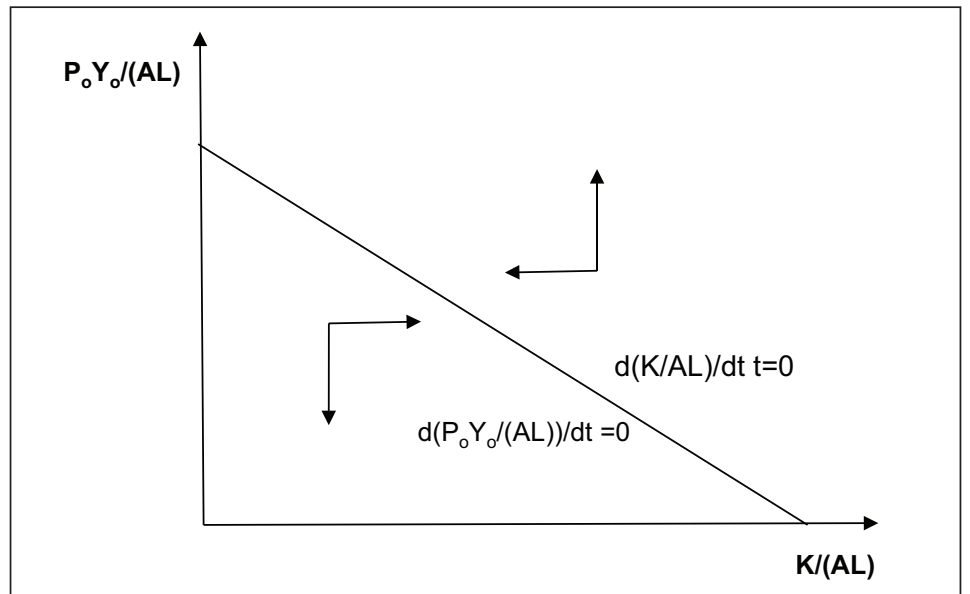

If the upwards shift of $\widehat{p}_{o}+\widehat{\Upsilon}_{o}-\hat{A}-\widehat{L}=0$ is strong enough, so that it now lies above $R-\hat{A}-\hat{L}=0$ regardless of the latter shifting right or left, the economy moves to scenario 2 . Under these conditions the equilibrium $E_{1}$ is plausible, but not guaranteed. In this case, the improvement is access to credit makes feasible a formal labour improving growth type.

In scenario 2, if the credit crunch is relaxed the hold of the "growth trap" is reduced. In fact, the economy could escape the trap, because the curve SS shifts to the right. Improving the access to credit improves growth rates of economies not in the trap as well. If $x$ decreases, long-run steady-state $E_{1}$ increases. In scenario 2, the participation of the extractive sector in the total economy is now decreasing: long-run growth is determined by $A>\rho$ and $A$ increases with the improvement of credit conditions. It is worth to not to overlook, however, that (as already shown in third section above) without supplementary policies the higher "per capita" income may not be reaped by formal workers in the form of more formal sector employment.

In summary, quality growth, where labour growth in the formal sector actually increase, requires that the economy first reaches the scenario 2 . In such situation $\widehat{p_{o}}+\vec{Y}_{o}-\hat{A}-t<0$, and $R-A-t=0$ : the long-run growth in the extractive sector does not exceed the maximum sustainable growth of the modern sector $\rho<R$. If for some reason the economy is in scenario 1 , it is still recommendable to improve financial conditions, because it then could move to a more promising situation although it would not necessarily converge towards $E_{1}$. But it is worth highlighting (again) that even if modern sector increases, supplementary policies are required to promote modern sector employment. In any case, in our logic of analysis, $E_{1}$ is 
preferable to $\frac{K}{A L} \rightarrow 0, \frac{p_{o} Y_{o}}{A L} \rightarrow \infty$, because in the latter economic growth does not imply benefits for domestic workers.

The intuition for which improving the financial conditions in either case (scenario 1 or 2) is a good policy is that relaxing the credit crunch makes accumulation stronger for the same formal employment and, therefore, the same wage share: it eases accumulation without squeezing capitalists' profits.

\section{CONCLUSIONS}

This paper presented a structuralist theoretical model which casts light on the role of credit restrictions in developing countries, where a modern (formal) sector with a relatively high capital intensity, coexists with a labour-intensive informal sector. Our model has innovative features when compared to neoclassic contributions on this line of scholarship, by including a third, extractive sector.

The extractive sector is oriented to exporting goods intensive in natural resources, and it is usually owned by foreign firms. In addition, it exhibits scarce or null linkages with the rest of the economy.

The modelling strategy is based upon stylized facts and characteristics of the contemporary Colombian economy, where a relatively large and growing extractive sector (mining) coexists with a modern (manufacturing and tradable services) and informal (survivalist) sectors. The performance of this economy has been underwhelming since neoliberal reforms in the 1990s, a period during which the extractive and informal sectors have gained participation. We believe, however, that these features may be found in other developing countries as well. Empirical research along these lines naturally arises as a topic of future research.

The first conclusion drawn from our theoretical model is that relaxing credit restrictions increases productivity, capital accumulation and growth of the modern sector but, however, supplementary policies are required in order to also increase formal labour. This seemingly paradoxical result is actually logical, because of the following. On the one hand, expanded credit increases capital intensity. But, on the other hand, it also increases labour productivity, a labour-saving process. So, it is possible the latter effect is stronger than the former and thus workers have to remain in the informal sector in spite of modern sector growth.

From the dynamic analysis of this paper we showed that if the extractive sector growth is higher than the sustainable growth rate of the modern sector, the economy will converge to a certainly undesirable "growth path", in which only the extractive sector is increasing. This result follows from the fact that the extractive sector growth is exogenous, with negligible linkages to the local economy. The second finding of our theoretical inquiry is that the probability of ending up in this undesirable scenario decreases when credit restrictions are relaxed.

In short, this paper conveys two key messages for "three-sector" developing economies. First, relaxing the credit restrictions is definitely a desirable policy objective, because it increases growth in the modern sector, and it increases the likeli- 
hood of escaping the growth pattern in which the extractive sector increases but the modern one disappears. Second, even if the economy successfully escaped the "extractivist trap", it is still needed to have supplementary formal job creation policies, intending to guarantee modern sector labour growth actually occurs. Stating what exactly these supplementary policies should look like requires, however, a comprehensive and rigorous effort which is beyond the scope of this paper. We should leave this important topic open for future research.

\section{REFERENCES}

Banerjee, A. V., \& Duflo, E. (2011) Poor Economics. A Radical Rethinking of the Way to Fight Global Poverty. Public Affairs.

Banerjee, A. V., \& Duflo, E. (2014) “Do Firms Want to Borrow More? Testing Credit Constraints Using a Directed Lending Program”. The Review of Economic Studies, 81(2), 572-607.

Brando, C. (2016). "Winners and losers in the allocation of credit during the era of import-substitution industrialisation in Colombia, 1940-1967.” Ensayos sobre Política Económica, 34(79), 21-39.

Castro, D.; A. Pérez \& S. Domínguez (2017). “Estimación de la probabilidad de incumplimiento para las firmas del sector económico industrial y comercial en una entidad financiera colombiana entre los años 2009 y 2014”. Cuadernos de Economía, 36(71), 293-319.

Delgado, C. 2004. "Inversión y restricciones crediticias en Colombia en la década de los noventa". Ensayos Sobre Política Económica, 22(47), 8-55.

Díaz, V. (2014), “Crédito privado, crédito bancario y producto interno bruto: evidencia para una muestra suramericana”. Ensayos sobre Política Económica, 32(73),104-126.

Eslava, et al.., (2010), "Scarring Recessions and Credit Constraints: Evidence from Colombian Plant Dynamics"; Serie Documentos Cede No. 2010-27, 1-44.

Fazzari, S., Hubbard, R., \& Petersen, B. (1988). "Financing Constraints and Corporate Investment". Brookings Papers on Economic Activity, 1988(1), 141-206.

Garcia, J. (2002), "Liberalización, cambio estructural y crecimiento económico en Colombia. Cuadernos de Economia, 21(36), 189-244.

Garza, N. (2016), The spatial and long term evolution of land prices in a Latin American metropolis: the case of Bogotá, Colombia”. Revista de Economía del Caribe, 18, 11-35.

Gómez-Ramírez, L. (2019). "Credit Constraints and Investment in Mexico, an Empirical Test”. Revista Mexicana de Economía y Finanzas, 14(3), 415-432.

Gutiérrez, J. \& A. Murcia (2015). “El papel de la estructura del sistema financiero en la transmisión de la política monetaria”. Ensayos sobre Política Económica, 33(76), 44-52.

Khwaja, A., \& Mian, A. (2008). "Tracing the Impact of Bank Liquidity Shocks: Evidence from an Emerging Market”. The American Economic Review, 98(4), 1413-1442.

Martins, G. K. \& Skott, P. (2020) "Sources of inflation and the effects of balanced budgets and inflation targeting in developing economies”. UMass Amberst Economics Working Papers, 291.

Ocampo, J. A., Avella, M., Bernal, J. \& Errázuriz, M. 2015. “La industrialización y el intervencionismo estatal (1945-1980)”, en Historia económica de Colombia (J. A. Ocampo, ed.) Fondo de Cultura Económica.

Ortiz, C; J. Uribe \& H. Vivas (2013), "Productividad, acumulación y deseconomías públicas en el crecimiento económico colombiano.” Cuadernos de Economia, 59(32), 235-265.

Restrepo, M. \& D. Restrepo (2007), “El canal del crédito bancario en Colombia: 1995-2005. Una aproximación mediante modelos de umbral”. Lecturas de Economía, 67, 99-118.

Restrepo, S.; J. Niño \& E. Montes (2014), "Comercio exterior colombiano y su financiación con la banca local: un análisis a nivel de firma”. Lecturas de Economía, 81, 115-153. 
Ros, J. (2013a). Algunas tesis equivocadas sobre el estancamiento económico de México. México: El Colegio de México - Universidad Nacional Autónoma de México.

Ros, J. (2013b), Rethinking Economic Development, Growth, and Institutions. Oxford University Press.

Skott, P. (2021). "Fiscal Policy and Structural Transformation in Developing Economies". Structural Change \& Economic Dynamics, 56, 129-140.

Skott, P. \& L. Gómez-Ramírez (2018), "Credit Constraints and Economic Growth in a Dual Economy”. Structural Change \& Economic Dynamics, 45, 64-76.

Skott, P. \& M. Larudee (1998). "Uneven development and the liberalisation of trade and capital flows: the case of Mexico". Cambridge Journal of Economics, 22(3), 277-295.

Villar, L., Salamanca, D., \& Murcia, A. (2005). "Crédito, represión financiera y flujos de capitales en Colombia: 1974-2003”. Desarrollo y Sociedad, 55(2005), 167-209.

Yepes, D. \& D. Restrepo-Tobón (2016). "Determinantes del nivel de efectivo de las compañías colombianas". Lecturas de Economía, 85, 243-276.

Zerda, A. (2015), "La economía de Colombia, entre la apertura y el extractivismo". Documento Escuela de Economia 68, Universidad Nacional de Colombia.

\section{APPENDIX 1: EFFECTS OF CHANGES IN CREDIT RESTRICTIONS}

Using (2)-(30) we have:

$$
R-\hat{p}_{o}-Y_{o}=F\left(\frac{K}{A L}, \frac{p_{o} Y_{o}}{A L}, x\right)-\rho
$$

When evaluated in the locus $\frac{p_{o} Y_{o}}{A L}=0$, the right-hand side of this last equation can be presented as:

$$
R-\hat{p}_{o}-Y_{o}=g^{-1}(\rho-f(x)-n)-\rho
$$

The right-hand side of (A1) is increasing in $x$. Consequently, a decrease in $x$ (improvement in credit access) must diminish $R-\hat{A}-\hat{L}$ at the locus $\frac{p_{o} Y_{o}}{A L}=0$. This result prevents a re-switching from scenario 2 to scenario 1 after credit restrictions are relaxed. In scenario $2, \hat{K}-\hat{A}-\hat{L}$ is negative at the locus $\frac{p_{o} Y_{o}}{A L}=0$. It is positive in scenario 1. 